\title{
Thread-drifting juvenile Mytilus spp. in continental shelf waters off Coos Bay, Oregon, USA
}

\author{
Alan L. Shanks ${ }^{1, *}$, R. Kipp Shearman ${ }^{2}$ \\ ${ }^{1}$ Oregon Institute of Marine Biology, University of Oregon, PO Box 5389, Charleston, Oregon 97420, USA \\ ${ }^{2}$ College of Oceanic and Atmospheric Sciences, 104 COAS Administration Building, Oregon State University, Corvallis, \\ Oregon 97331, USA
}

\begin{abstract}
On 4 sample dates in summer 2007, vertically stratified zooplankton samples and oceanographic data were collected at 7 stations located from 0.5 to $28 \mathrm{~km}$ from shore near Coos Bay, Oregon, USA. Two of the sample dates (27 June and 14 August) were characterized by upwelling conditions and the other two (3 and 18 July) by downwelling or relaxation. We identified larval and threaddrifting Mytilus californianus and M. trossulus/galloprovincialis. Thread-drifting M. californianus and M. trossulus/galloprovincialis ranged in size from 306 to $627 \mu \mathrm{m}$ and from 305 to $832 \mu \mathrm{m}$, respectively. On all sample dates, larval and thread-drifting mytilids were rare in surface waters (0 to $10 \mathrm{~m}$ depth), abundant below these depths at the 3 inshore stations ( 0.7 to $4.5 \mathrm{~km}$ offshore) and rare or absent at all depths at more seaward stations. Thread drifters were caught within 10s of meters of the bottom. There was no relationship between either the strength of the alongshore currents or wave energy and the abundance of thread drifters. Thread drifters were significantly more abundant during downwelling/relaxation events than during upwelling events. The higher abundances during downwelling may be due to favorable conditions for thread drifting within the benthic boundary; density instability generated by the downwelling circulation interacting with the cross-shelf density gradient creates vertical currents, which may aid lift-off of thread drifters from the bottom.
\end{abstract}

KEY WORDS: Mytilis · Thread drifting $\cdot$ Upwelling $\cdot$ Downwelling

- Resale or republication not permitted without written consent of the publisher

\section{INTRODUCTION}

Shanks \& Shearman (2009) tested the hypothesis that upwelling transports larvae of intertidal invertebrates offshore away from coastal settlement sites and downwelling transports them toward shore. During the analysis of zooplankton samples collected for that study, mytilids between 350 and >800 $\mu$ m were regularly encountered. These individuals are larger than typical larval mytilids, suggesting that they were settlers that had metamorphosed into benthic juveniles, and were present in the water column as thread drifters; they were in the process of performing a secondary or postsettlement migration at the time they were captured. Thread drifting has been commonly observed in estuaries and other bodies of water with strong tidal currents, but observations of thread drifters are rare in continental shelf waters, and there are no reports in the literature for the west coast of North America. The present paper investigates the distribution of these secondary dispersers and relates their presence in the water column to hydrographic conditions.

Secondary dispersal of benthic juveniles is a common occurrence in bivalves (Sigurdsson et al. 1976, Martel \& Chia 1991). The thread-drifting behavior in bivalves is very similar to that of ballooning in young spiders (Humphrey 1987). Tiny juvenile spiders, typically recently hatched individuals, climb to the top of some taller object (e.g. twig, blade of grass) and perform what is known as tip-toe behavior. When the spider perceives the right conditions (the behavior is clearly initiated by the spider), it releases a meters long thin thread, which is carried away by the breeze. As 
the drag on the thread increases, the spider is pulled to its 'tip-toes' and eventually, if the drag is great enough, lifted into the air. For spiders, the right conditions appear to be moderate winds, as ballooning drops off if winds are too slow or fast. Up-drafts caused by solar heating are especially important for ballooning to occur (Reynolds et al. 2007). If winds are simply horizontal, a ballooning spider will be transported horizontally, but, despite the slower fall rate due to the drag on the spider thread, gravity will soon pull it back to the ground limiting the amount of horizontal transport. To be transported a significant distance, the spider needs to be lifted high enough off the ground; hence, updrafts are needed for successful ballooning. The number of ballooning spiders increases on days characterized by warm thermal vertical advection (Greenstone 1990).

In some bivalve species, secondary dispersal has been observed often; the larvae settle into a habitat different from that of the adult, and migration of thread drifting juveniles into the adult habitat occurs during a secondary dispersal (Bayne 1964, Beukema \& de Vlas 1989). In bivalves, the benthic juvenile secretes a long slender mucus thread. Under the appropriate hydrodynamics, drag on the thread can become great enough to lift the individual off the bottom and into the water column where it is transported by the currents; this is known as thread drifting (Sigurdsson et al. 1976, Lane et al. 1985). Surprisingly large individuals (>2 $\mathrm{mm}$ ) can perform a secondary dispersal by thread drifting (Sigurdsson et al. 1976). This suggests the hypothesis that periods of stronger wave activity or faster currents should be associated with a greater abundance of thread drifters in the water column. We compared the abundance of thread drifting mytilids to wave energy, winds and surface currents on the day of the collections. As with ballooning spiders, up-drafts may also be important and, in the coastal environment in which we were working, 'up-drafts' in the water column can be caused by downwelling or relaxation events (Trowbridge \& Lentz 1991); hence, we also compared the abundance of thread drifters to upwelling and downwelling conditions.

\section{MATERIALS AND METHODS}

On each of 4 dates during summer 2007 (27 June and 14 August, upwelling conditions; 3 and 18 July, downwelling/relaxation conditions) 7 stations along a transect located $\sim 6 \mathrm{~km}$ north of the mouth of Coos Bay, Oregon, USA, were sampled (see Shanks \& Shearman 2009 for a detailed description of the sampling protocol). The most inshore station was 0.5 to $0.7 \mathrm{~km}$ from shore and the most offshore station was $28 \mathrm{~km}$ off- shore. At each station we made a CTD cast with a CTD profiler (SeaBird, model 19) and collected stratified zooplankton samples. Data from the CTD casts were used to determine the zooplankton sample depths. Depending on station depth, we sampled 5 (station depth $>70 \mathrm{~m}$ ), 4 (ca. 30 to $70 \mathrm{~m}$ ) or $3(\leq 30 \mathrm{~m})$ depth strata.

Zooplankton samples were collected with a small Tucker trawl $(0.25 \times 0.25 \mathrm{~m}$ with $202 \mu \mathrm{m}$ mesh). The net was equipped with a messenger-activated release that allowed nets to be opened and closed at depth. Flow meters in the nets were used to determine the volume of water filtered (filtered volume ranged from 5 to $20 \mathrm{~m}^{3}$ ). Sample depth was determined by the standard technique of measuring wire angle and the length of wire out.

Zooplankton samples were preserved in the field with buffered formalin. In the laboratory, the samples were washed free of formalin on a $53 \mu \mathrm{m}$ sieve. The sample was transferred to a $300 \mathrm{ml}$ beaker and the sample, with the aid of an electronic balance, was made up to $200 \mathrm{ml}(200 \mathrm{~g})$ with water. The sample was thoroughly mixed by vigorous random stirring, and subsamples were removed with a Stempel pipette (Peterson et al. 1979, Omori \& Ikeda 1984). Samples were inspected with an inverted compound microscope at $40 \times$ magnification and, when needed for identification, 100x. We identified the larvae and juvenile stages of Mytilus californianus and M. trossulus/galloprovincialis using the criteria described in Martel et al. (1999, 2000). Larval and juvenile $M$. trossulus and $M$. galloprovincialis cannot be visually separated so the 2 species were combined. However, M. galloprovincialis is uncommon in the study area (Carlton 2007), and most of the individuals identified as $M$. trossulus/galloprovincialis were probably $M$. trossulus.

The shell lengths of larvae and juveniles were measured with an ocular micrometer. In samples where mytilids were abundant, lengths of a hundred or more individuals were measured. Where mytilids were uncommon (e.g. 14 August samples), the lengths of all individuals in the entire sample were measured. Mytilids were quite rare (at most one to several per sample) in the samples from the more offshore stations (stations beyond $5 \mathrm{~km}$ ) and no attempt was made to search for these rare individuals and measure their sizes. In these formalin-preserved samples, we could not differentiate between larvae and juveniles by inspecting their internal anatomy; the individuals were too opaque. During the pelagic stage, the larval shell takes the form of the prodissoconch II (PII), but at the transition from larvae to benthic juvenile the PII shell stops being produced and is replaced by a juvenile shell (Zardus \& Martel 2002). To determine the size of larvae just before settlement occurs we copied a tech- 
nique used by Nelson (1928). In larger individuals, when the illumination was right, the transition from the PII to the juvenile shell was apparent. For these individuals, we measured both the total shell length and the length of the PII shell; the average size of individuals at the transition from the PII shell to the juvenile shell was used as the average size at metamorphosis for each taxa.

Thread drifters are suspended off the bottom by currents. This suggests that periods of stronger wave activity or faster currents are associated with a greater abundance of thread drifters in the water column. We compared the abundance of thread-drifting mytilids to wave energy, winds and surface currents on the day of the collections. Wave data were obtained from the NOAA Stonewall Bank buoy (Stn 46050, $44.64^{\circ} \mathrm{N}$, $124.5^{\circ} \mathrm{W}$ ), which is approximately $120 \mathrm{~km}$ north of the study site. Wave energy data across a wide range of wave periods were summed for the $24 \mathrm{~h}$ before the initiation of sampling. Hourly wind data were obtained from the NOAA Port Orford, Oregon, weather buoy (Stn $46015,42.76^{\circ} \mathrm{N}, 124.83^{\circ} \mathrm{W}$ ), which is located $30 \mathrm{~km}$ offshore and about $85 \mathrm{~km}$ south of the study site. The average alongshore component of the winds (roughly north- south wind speed) was calculated for the $24 \mathrm{~h}$ before sampling. Current speeds below the surface and within the water column were not available. Surface current speeds in the alongshore and cross-shore directions were obtained from M. Kosro at Oregon State University, College of Oceanic and Atmospheric Studies (http://bragg.coas.oregonstate. edu/ORCoast/); high frequency radar was used to map average daily surface currents speeds along much of the Oregon coast. A detailed description of the sampling procedure can be found at the above web site. During the upwelling season along the Oregon coast, alongshore currents at depth generally travel in the same direction as surface currents (Huyer 1983). In contrast, nearshore cross-shore surface currents generally move in the opposite direction from currents at depth (Huyer 1983). During upwelling, surface currents are offshore and deep currents are onshore, while during downwelling the reverse is true. Surface currents are generally faster than currents at depth.

\section{RESULTS}

The size of larval PII shells at the time of transition to the juvenile shell in Mytilus trossolus/galloprovincialis ranged from 255 to $331 \mu \mathrm{m}$, with an average size $\pm \mathrm{SD}$ of $305 \pm 17 \mu \mathrm{m}(\mathrm{n}=18)$; individuals larger than $330 \mu \mathrm{m}$ were considered to be thread drifters. When the transition in shell type in $M$. californianus occurred, the shell length ranged from 280 to $336 \mu \mathrm{m}$ with an average size of $306 \pm 18 \mu \mathrm{m}(\mathrm{n}=64)$; individuals larger than $340 \mu \mathrm{m}$ were considered to be thread drifters. Individuals that settle and metamorphose in the intertidal zone develop dark shells after several days of exposure to the sun (Trevelyan \& Chang 1987). A dark shell, hence, is an indication that an individual has resided in the intertidal for at least several days. There was no darkening of the margin of the shell in any of the thread-drifting individuals, suggesting that they had not spent time in the intertidal zone, but had settled in the subtidal zone.

Over the course of the summer, the number of mytilid larvae and thread drifters steadily decreased. The abundances of the 2 taxa on each sample date were similar (Shanks \& Shearman 2009). The highest abundance (maximum, tens of thousands per square meter) was observed on 27 June and maximum concentrations decreased by about a factor of 10 on each sample date, such that by 14 August the maximum abundance was on the order of tens per square meter.

Very few or no individuals of either taxon were caught in surface tows, and individuals with shell lengths indicative of thread drifters were present on all dates. Concentrations of thread drifters ranged from $>1000$ to $<1 \mathrm{~m}^{-3}$ (see Figs. $2 \& 3$ ). Higher percentages of the mytilids were found to be thread drifters on the 2 sampling dates in July (downwelling/relaxation conditions) than in the June or August samples (upwelling conditions) (Table 1). In addition, on the downwelling/ relaxation sample dates, there were more large thread drifters $(>400 \mu \mathrm{m})$ found than on the 2 dates with upwelling conditions (Fig. 1). These larger thread drifters tended to be caught in the deeper samples collected at the 2 most nearshore stations (black bars in Figs. 2 \& 3).

There were no significant correlations between the percentage of thread drifters and the summed wave energy or alongshore surface current speeds (Table 1). The percentages of all thread drifters and large thread drifters $(>400 \mu \mathrm{m})$ in the samples were, however, both significantly correlated with cross-shelf surface current speeds; higher percentages of thread drifters were present on dates when surface currents were indicative of downwelling conditions (Fig. 4). The percentage of thread drifters and large thread drifters was much lower on dates with upwelling favorable winds than on dates with winds indicative of downwelling/ relaxation (Fig. 4).

\section{DISCUSSION}

The size at settlement and metamorphosis of Mytilus trossulus/galloprovincialis $(320 \mu \mathrm{m})$ and M. californianus $(330 \mu \mathrm{m})$ was estimated by measuring the size of 
Table 1. Mytilus trossulus/galloprovincialis and M. californianus. Percentage of the total mytilids present in the water on each sampling date that were thread drifters (i.e. $M$. tros/gal: M. trossulus/galloprovincialis $>320 \mu \mathrm{m}$; . cal: M. californianus $>330 \mu \mathrm{m}$ ) and (in parentheses) large thread drifters (i.e. $M$. tros/gal: M. trossulus/galloprovincialis $>420 \mu \mathrm{m} ; M$. cal: . californianus $>430 \mu \mathrm{m}$ ). The summed wave energy, cross-shore and alongshore surface current speeds and north-south component of wind speed are also shown for the respective sampling days

\begin{tabular}{|lcccccc|}
\hline Date & $\begin{array}{c}\text { Thread drifters } \\
\text { (large thread drifters) } \\
(\%)\end{array}$ & $\begin{array}{c}\text { Summed } \\
\text { wave } \\
\text { energy }\end{array}$ & $\begin{array}{c}\text { Surface current } \\
\text { speeds }\left(\mathrm{cm} \mathrm{s}^{-1}\right) \\
\text { Cross- } \\
\text { Along- } \\
\text { shore }\end{array}$ & $\begin{array}{c}\text { N-S wind } \\
\text { shore }\end{array}$ & $\begin{array}{c}\text { speed, } \\
\left(\mathrm{m} \mathrm{s}^{-1}\right)\end{array}$ \\
\hline 27 Jun & $14(0)$ & $23(0.3)$ & 127 & -9.33 & -5.68 & 4.2 \\
3 Jul & $42(8)$ & $67(32)$ & 236 & 6.57 & -6.77 & -3.4 \\
18 Jul & $33(4)$ & $60(27)$ & 114 & -1.03 & 11.04 & -5 \\
14 Aug & $7(0)$ & $6(0)$ & 102 & -10.03 & -16.87 & 2.3 \\
\hline
\end{tabular}

the PII shell in large individuals that had both PII and juvenile shell material. Some of the individuals larger than the average maximum PII shell length may still have been larval; they may have been delaying metamorphosis due to a lack of suitable settlement habitat. However, individuals of either taxa larger than $400 \mu \mathrm{m}$ were undoubtedly juveniles, and individuals this large were common (Fig. 1). At metamorphosis, mytilids lose the ability to swim; hence, individuals larger than the average maximum PII shell length were most probably thread drifters.
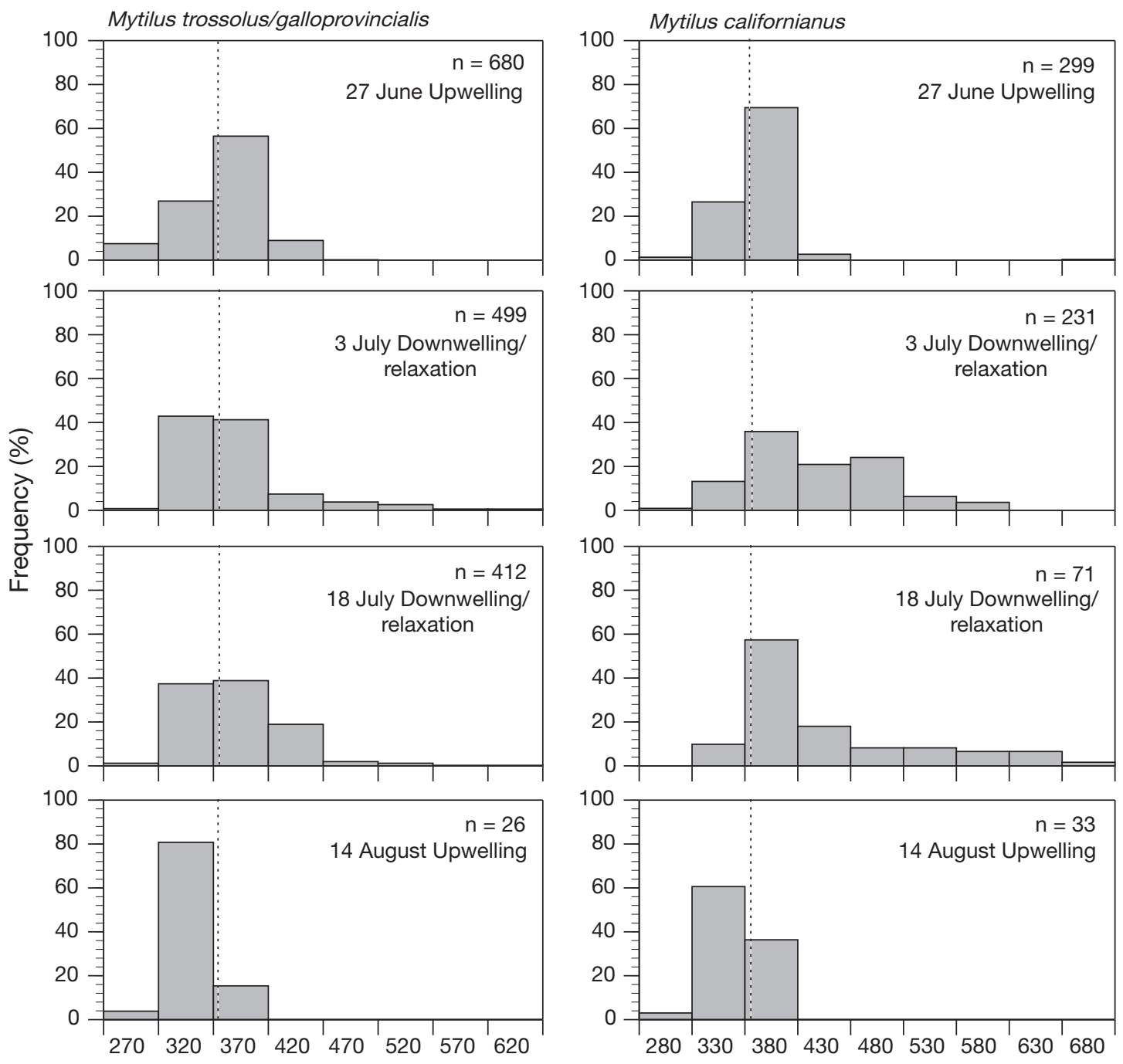

Size bins, $\mu \mathrm{m}$

Fig. 1. Mytilus trossolus/galloprovincialis and M. californianus. Size frequency distributions (\%) for M. trossolus/galloprovincialis (left panels) and $M$. californianus (right panels) observed in the samples collected on 4 dates during the summer of 2008. On 2 dates (27 June and 14 August) conditions were favorable for upwelling events and on 2 dates (3 July and 18 July) conditions favored downwelling or relaxation events. Dashed vertical line in each graph indicates the approximate size of the larvae at the time of transition from pelagic larvae (to the left of the line) to thread drifters (to the right of the line); note the different values on the $x$-axes 
June 27
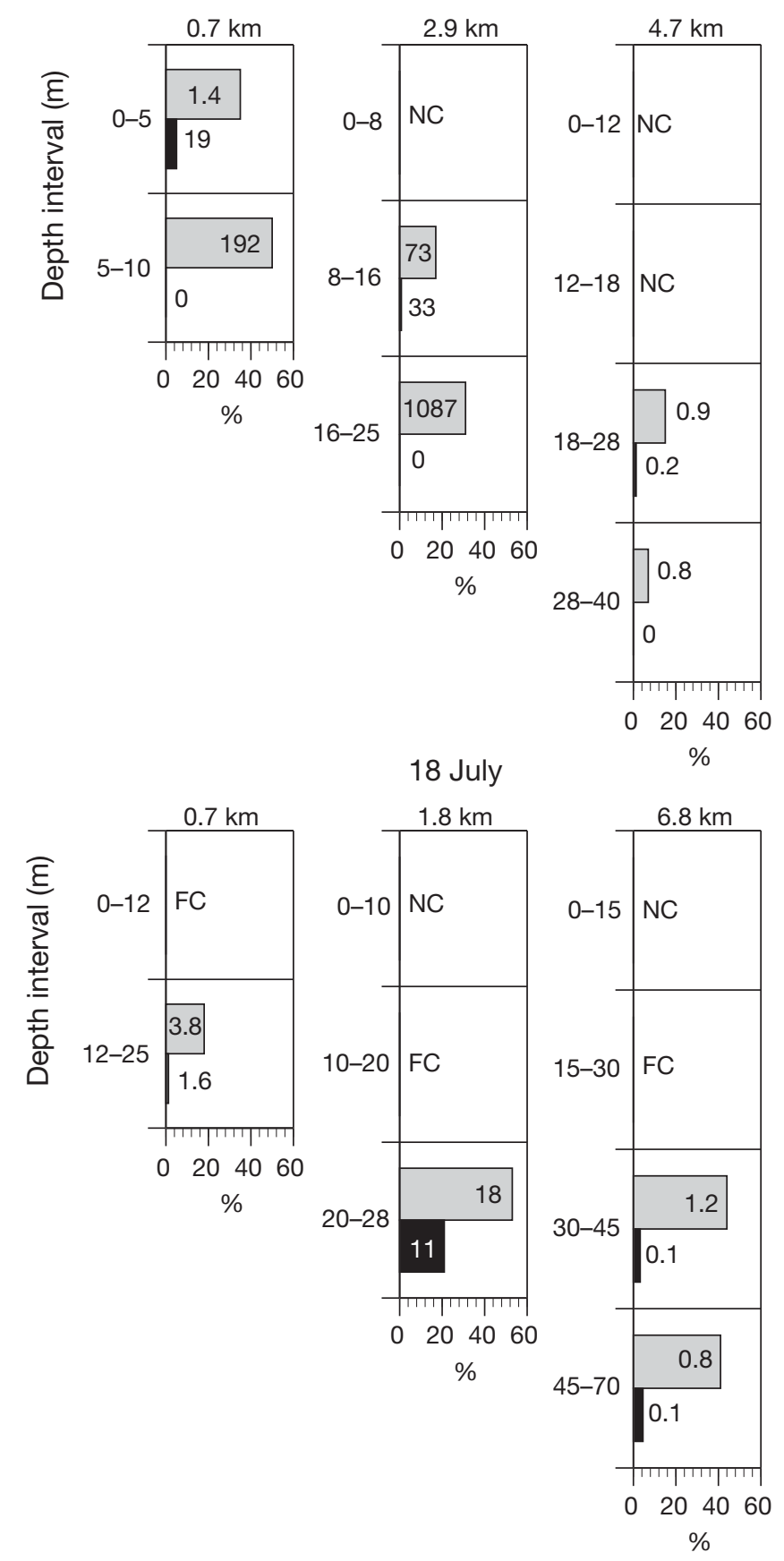
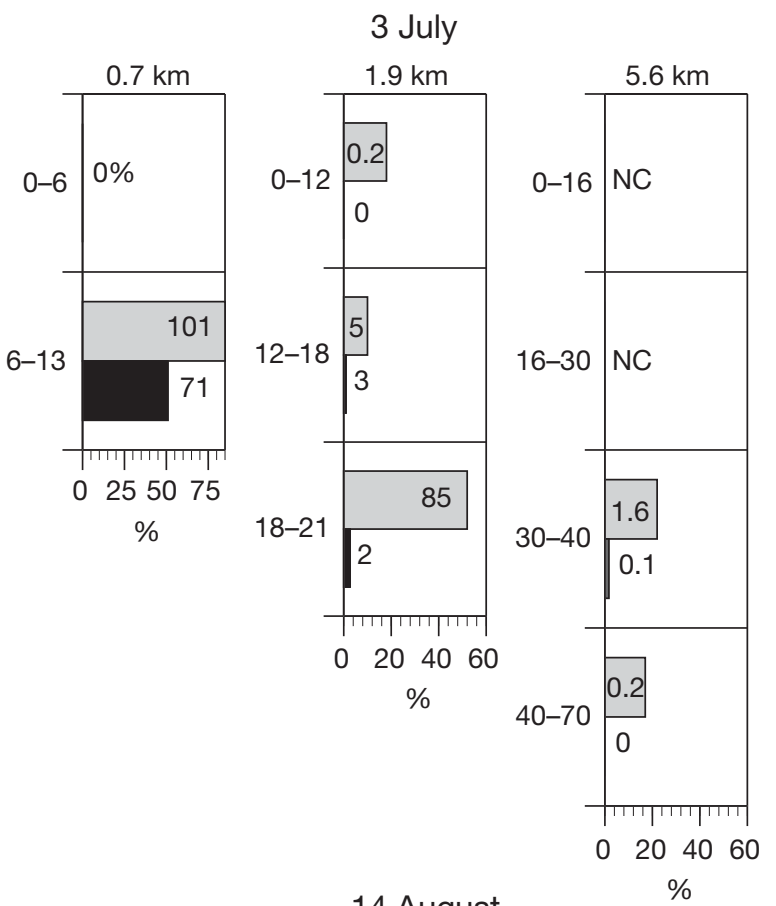

14 August
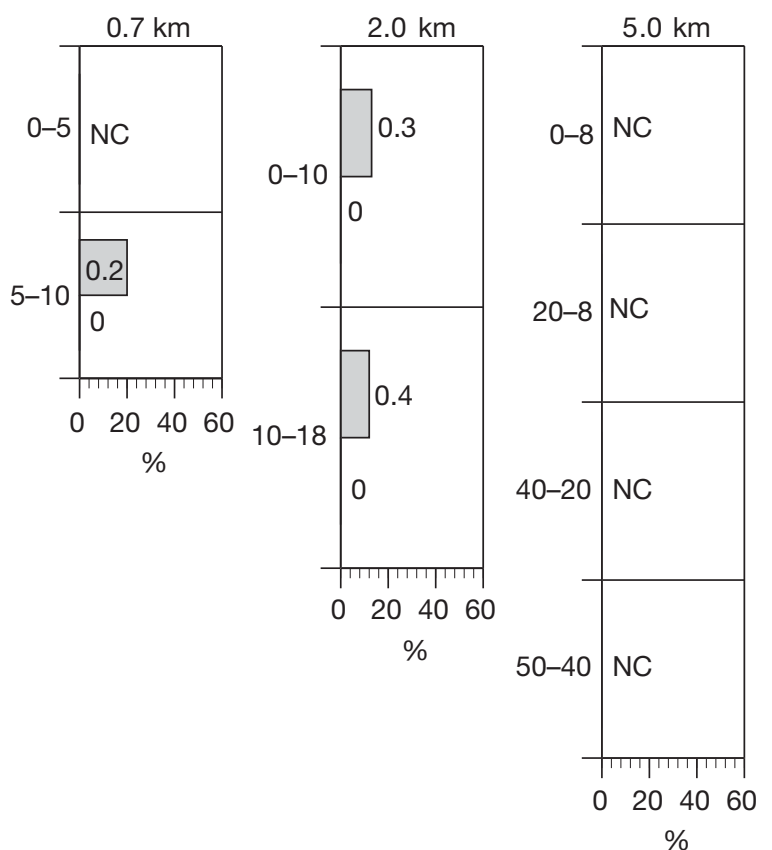

Fig. 2. Mytilus trossolus/galloprovincialis. Cross-shelf and vertical distribution of thread-drifting M. trossolus/galloprovincialis sampled on 3 dates during the summer of 2008 (the August samples were not included in this analysis as too few individuals were caught). Gray and black bars indicate the percentage of individuals $>320 \mu \mathrm{m}$ and individuals $>420 \mu \mathrm{m}$ in length, respectively. Values within or immediately to the right of each bar are the number $\mathrm{m}^{-3}$ for each size class. Value at the top of each graph is the distance offshore. NC: no individuals counted; FC: too few individuals caught for this analysis

The vertical and cross-shelf distributions of thread drifters were similar to the distributions of larvae; neither was present in the surface water samples, but both were most abundant at the 2 most nearshore stations, less abundant at the third station from shore and nearly absent in samples collected beyond the third station. While the largest individuals tended to be caught at the deepest sample depths they were still meters off the bottom; thread drifters were present even tens of meters off the bottom (Figs. 2 \& 3). Kilome- 

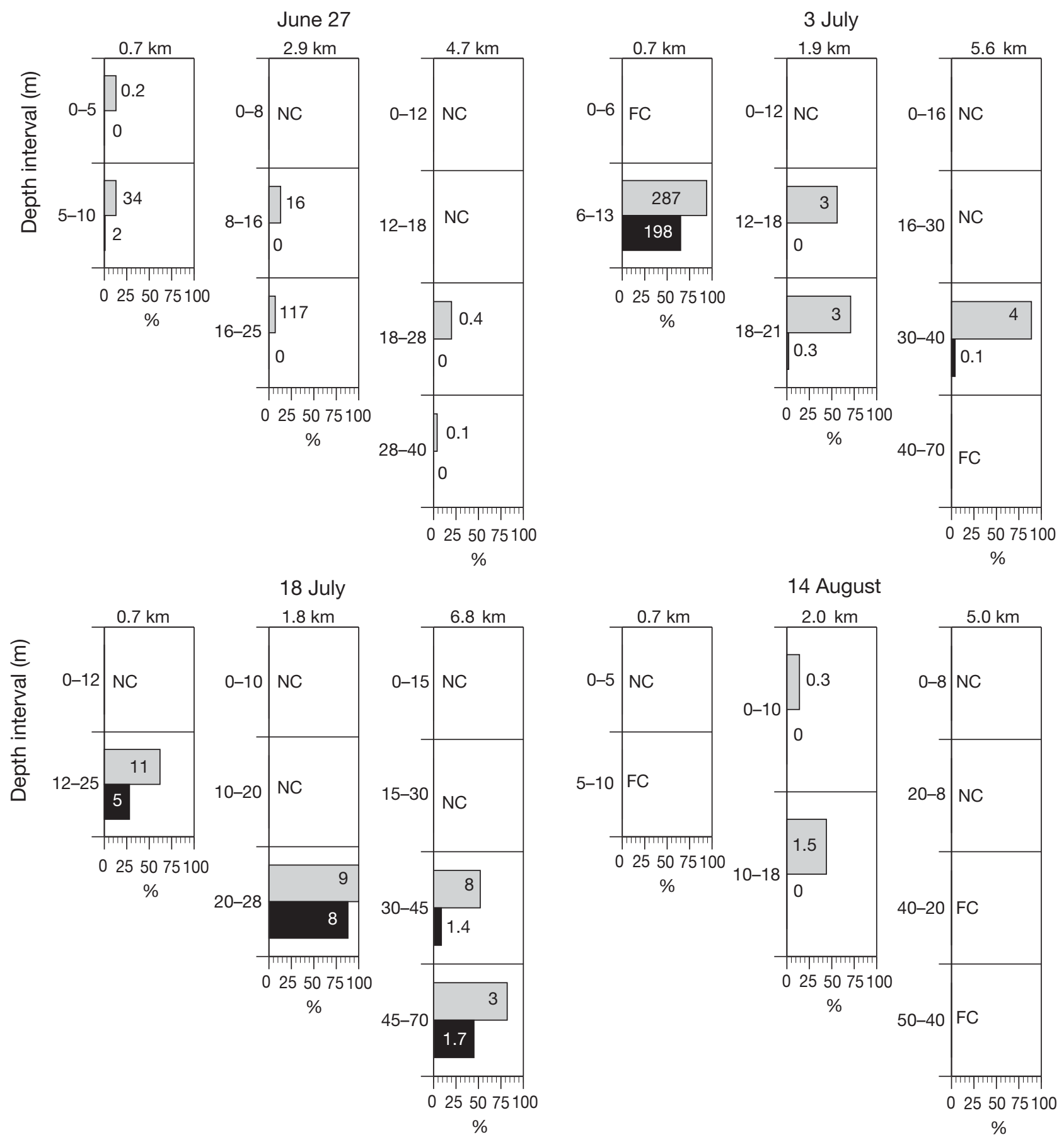

Fig. 3. Mytilus californianus. Cross-shelf and vertical distribution of thread drifting $M$. californianus sampled on 3 dates during the summer of 2008 (the August samples were not included in this analysis as too few individuals were caught). Gray and black bars indicate the percentage of individuals $>330 \mu \mathrm{m}$ and individuals $>430 \mu \mathrm{m}$ in length, respectively. Values within or immediately to the right of each bar are the number $\mathrm{m}^{-3}$ for each size class. Value at the top of each graph is the distance offshore.

NC: no individuals counted; FC: too few individuals caught for this analysis

ters from shore, juvenile thread drifters were clearly present and at times abundant. This is the first report of thread drifters present in continental shelf waters along the west coast of North America.
We can compare the abundance of thread drifters to hydrographic variables in this data set, but it should be borne in mind that the data set is small, with only 4 dates, and the data were collected along 1 transect line 

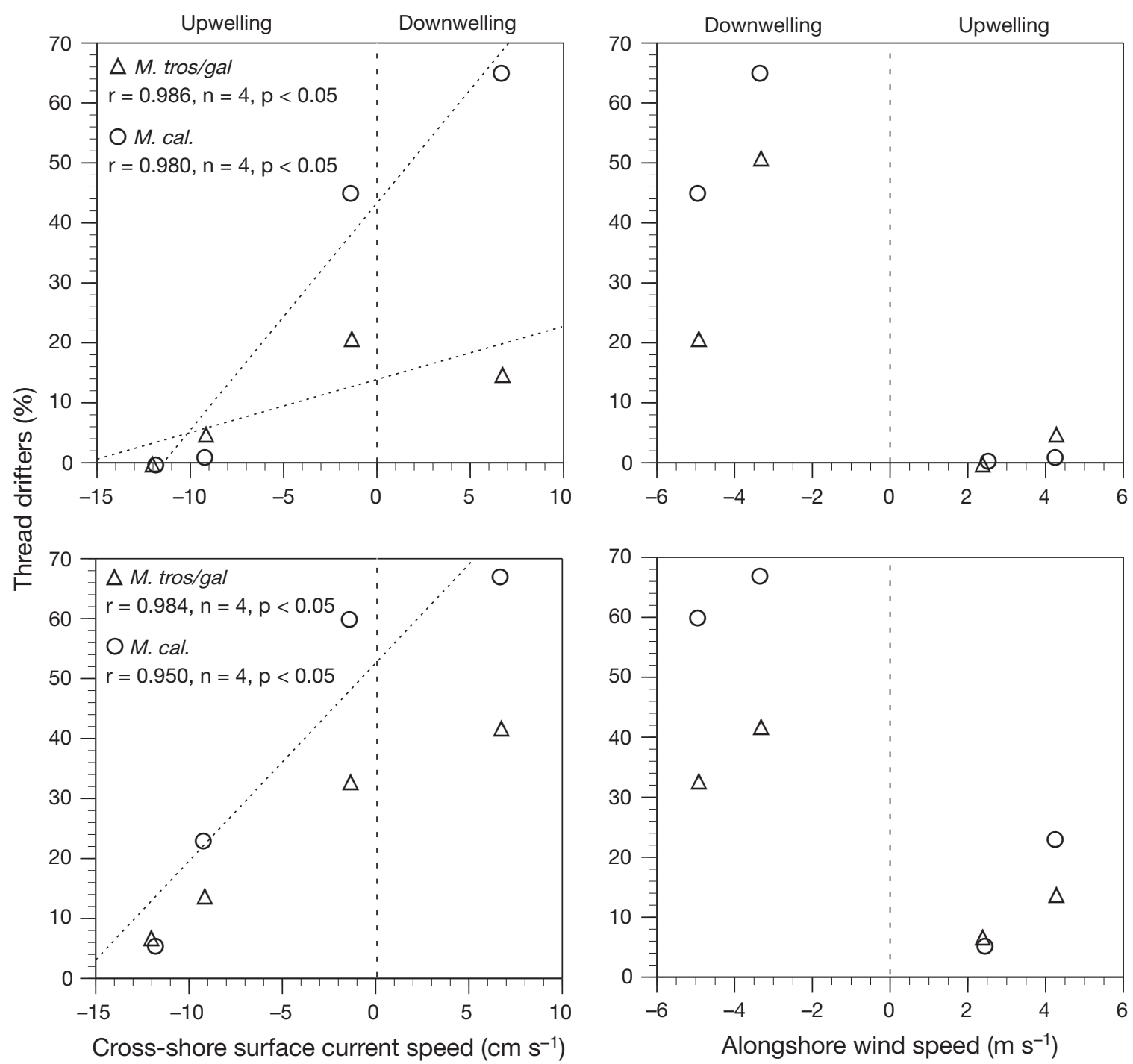

Fig. 4. Mytilus trossulus/galloprovincialis and M. californianus. Percentage of thread drifters (upper panels: $M$. trossulus/galloprovincialis $>320 \mu \mathrm{m}$, open triangles; $M$. californianus $>330 \mu \mathrm{m}$, open circles) and large thread drifters (lower panels: $M$. trossulus/galloprovincialis $>420 \mu \mathrm{m}$, open triangles; $M$. californianus $>430 \mu \mathrm{m}$, open circles) observed in the samples on each date plotted against cross-shore current speed (left panels) and alongshore wind speed (right panels). Positive values of cross-shore surface current speed indicate onshore surface flow (downwelling/relaxation), and negative values indicate offshore surface flow (upwelling). Positive alongshore wind speeds are indicative of winds that favor upwelling events, and negative values are indicative of winds that favor downwelling/relaxation events. Vertical dashed line indicates the separation between upwelling and downwelling/relaxation conditions

so provide hints rather than conclusive evidence as to what might be controlling the number of thread drifters present in the water column.

Martel (1993) found that juvenile zebra mussels Dreissena polymorpha were most abundant in the water column during periods when higher waves occurred, suggesting that the stronger currents during large wave events lifted more juveniles off the bottom. We found no relationship between the percentage of thread drifters and wave energy (Table 1). Beukema \& de Vlas (1989) observed thread drifting in Macoma baltic primarily in stronger tidal currents; peak abundance occurred at current speeds around $75 \mathrm{~cm} \mathrm{~s}^{-1}$. In laboratory studies of thread drifting in mytilids, suspension did not occur at current speeds of $<5$ to $7 \mathrm{~cm}$ $\mathrm{s}^{-1}$ (Lane et al. 1985), and speeds of surface alongshore and cross-shore currents at our study site off Oregon were at times faster than this; but, at the depths at which the thread-drifting juveniles were caught, current speeds would likely have been slower than the suspension speeds used in the laboratory. There was no relationship between the percentage of mytilids in 
the water column that were thread drifters and alongshore currents. Thread drifter abundances were consistently higher when southerly winds occurred (Fig. 4), which is when surface currents had a shoreward component indicative of downwelling or a relaxation from upwelling. Thread drifters were less abundant when surface currents were seaward (upwelling currents) even though surface currents at these times were faster than during downwelling events (Fig. 4). Despite the slower cross-shore current speeds, thread drifters were more common during downwelling conditions.

Thread drifters were significantly more abundant during downwelling/relaxation events than during upwelling events, suggesting that, like spider ballooning, thread drifting may require vertical advection. In spider ballooning, the vertical advection is due to solar heating of the air near the ground causing vertical thermal currents (Humphrey 1987). During the upwelling season off the Oregon coast (spring through summer) the winds vary to favor either upwelling or downwelling events (Huyer 1983). During upwelling, denser water from off the shelf is pulled shoreward and fills the nearshore water column. With the onset of downwelling, less dense surface water is pushed toward the shore where it downwells and is pushed seaward across the bottom. As this downwelled water is pushed offshore, it is forced under the denser upwelled waters (see Fig. 10 in Lentz \& Trowbridge 1991). The less dense downwelled waters beneath denser upwelled waters represent an unstable density distribution, and the less dense water will rise up into the water column causing density-driven vertical advection (Lentz \& Trowbridge 1991, Trowbridge \& Lentz 1991). This vertical advection causes a significant increase in turbulent mixing (Moum et al. 2004) and a subsequent deepening of the bottom boundary layer (Trowbridge \& Lentz 1991); the density-driven vertical advection is extensive enough to carry water tens of meters off the bottom. Thread drifters were most common in the samples during downwelling events, suggesting that the densitydriven vertical advection associated with downwelling may be a critical factor for thread drifting, especially in environments with lower current speeds, such as over the continental shelf.

At Stn 3 (4.7 to $6.8 \mathrm{~km}$ from shore), where full water column temperature measurements were consistently available, we computed the bottom mixed layer (BML) thickness, using a threshold of $0.05^{\circ} \mathrm{C}$ higher than the bottom-most temperature observation (e.g. Lentz \& Trowbridge 1991). Consistent with theory and previous observations (Lentz \& Trowbridge 1991, Trowbridge \& Lentz 1991), BML heights were 1.5 to 2.5 times larger during downwelling conditions than upwelling conditions (Table 2). There was no consis-
Table 2. Environmental conditions at Stn 3 on each sampling date: the station distance from shore, the bottom mixed layer (BML) height (computed in terms of a temperature threshold of $0.05^{\circ} \mathrm{C}$, see 'Discussion') and average temperature and salinity for the BML

\begin{tabular}{|lcccc|}
\hline Date & $\begin{array}{c}\text { Dist. from } \\
\text { shore }(\mathrm{km})\end{array}$ & $\begin{array}{c}\text { BML } \\
\text { height }(\mathrm{m})\end{array}$ & $\begin{array}{c}\text { BML temp. } \\
\left({ }^{\circ} \mathrm{C}\right)\end{array}$ & $\begin{array}{c}\text { BML } \\
\text { salinity }\end{array}$ \\
\hline 27 Jun & 4.7 & 12.1 & 7.5 & 33.9 \\
03 Jul & 5.6 & 22.5 & 7.5 & 33.9 \\
18 Jul & 6.8 & 18.3 & 8.4 & 33.9 \\
14 Aug & 5.0 & 8.8 & 8.6 & 33.8 \\
\hline
\end{tabular}

tent pattern in BML average temperature or salinity. The larger BML heights permit the lifting of particles and thread-drifting individuals higher in the water column, providing that the turbulent vertical speeds exceed the terminal velocity of thread-drifting individuals. This is highly likely in the case of coastal downwelling circulation; turbulent motions in the bottom boundary layer are significantly increased by the convective instability brought on by the interaction of the cross-shelf flow and the cross-shelf density gradient (Moum et al. 2004). Moum et al. (2004) found an overturning velocity scale of $1 \mathrm{~cm} \mathrm{~s}^{-1}$ on the central Oregon shelf; this velocity exceeds the terminal sinking velocity of typical thread drifters $<1 \mathrm{~mm}$ in size by an order of magnitude (Lane et al. 1985).

Following the analysis by Humphrey (1987) on spider ballooning, we examined the hydrodynamic conditions necessary for thread drifting in the bottom boundary layer. The analysis begins with the vertical forces acting on the larva at the point of lift-off, which are in balance with the forces acting on a larva in freefall that has achieved terminal velocity. The weight minus upward force due to the displaced water is balanced by the sum of the hydrodynamic drag acting on the larva body and long thread, modeled as a sphere (S) and thin rod (R): $M-B=F_{\mathrm{S}}+F_{\mathrm{R}}$, where $M$ is weight, $B$ is buoyant force due to the displaced water and $F_{\mathrm{S}}$ and $F_{\mathrm{R}}$ are the hydrodynamic drag forces acting on the larva body (a sphere) and long thread (a thin rod). The buoyant weight can be computed as:

$$
M-B=g \Delta \rho \frac{\pi D^{3}}{6}
$$

where $g$ is the gravitational constant, $\Delta \rho=0.078 \rho_{\mathrm{o}}$ is the difference between the larval density and seawater density, $\rho_{\mathrm{o}}\left(1025 \mathrm{~kg} \mathrm{~m}^{-3}\right)$, and $D$ is the diameter of the sphere $(200$ to $1000 \mu \mathrm{m})$. The drag on the sphere can be calculated as:

$$
F_{\mathrm{S}}=\frac{1}{2} \rho_{o} C_{D}^{\mathrm{S}} \pi \frac{D^{2}}{4} W^{2}
$$


where

$$
C_{D}^{\mathrm{S}}=\frac{24}{\mathrm{Re}}+\frac{6}{1+\sqrt{\mathrm{Re}}}+0.4
$$

is the Reynold's number $(\mathrm{Re}=W D / v)$ dependent drag coefficient used by Lane et al. (1985), $C$ is drag, $v=$ $1.044 \times 10^{-6} \mathrm{~m}^{2} \mathrm{~s}^{-1}$ is the kinematic viscosity and $W$ is the fluid velocity relative to the thread-drifting larva ( 0.0001 to $0.01 \mathrm{~m} \mathrm{~s}^{-1}$ ). Finally, the drag on the long thin rod is calculated as:

$$
F_{\mathrm{R}}=\frac{2 \pi \rho_{o} v W L}{\ln \left(\frac{4}{d} \sqrt{\frac{L v}{W}}\right)}
$$

where $L$ (3 to $30 \mathrm{~cm}$, Beukema \& de Vlas 1989) is the thread length ( $L \gg D$ ) and $d(0.5$ to $2 \mu \mathrm{m})$ is the thread diameter $(d \ll D)$. Drag by the thread is typically much greater than the drag on the sphere. Specifying values for $W$ and $L$, we can solve for the roots of $D$ in the range of values typical for thread-drifting larvae (Fig. 5).

During downwelling events vertical velocities in the bottom boundary layer can reach $1 \mathrm{~cm} \mathrm{~s}^{-1}$ (Moum et al. 2004), which far exceeds the necessary vertical velocity to lift a 300 to $500 \mu \mathrm{m}$ diameter larvae with threads ranging from 3 to $30 \mathrm{~cm}$ in length (Fig. 5). The window of necessary vertical velocities for thread drifting extends from $0.1 \mathrm{~mm} \mathrm{~s}^{-1}$ for smaller larvae (150 to $350 \mu \mathrm{m}$ diameter) to $1 \mathrm{~cm} \mathrm{~s}^{-1}$ for larger individuals (1 to

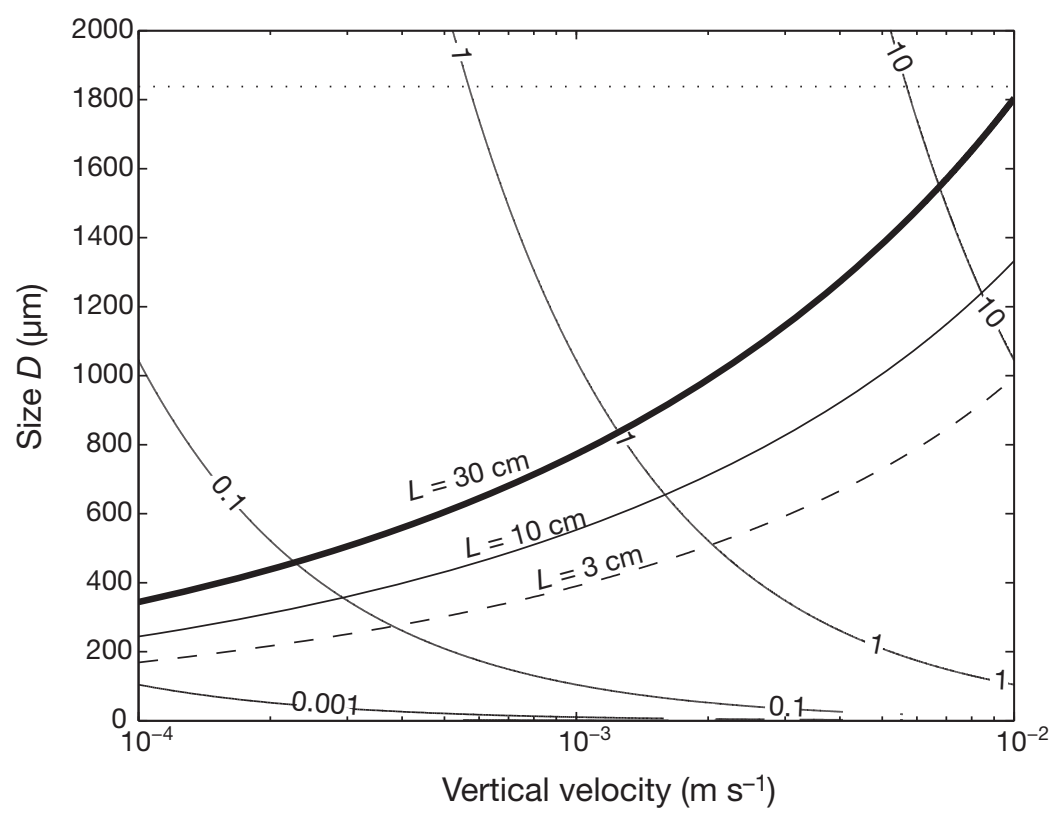

Fig. 5. 'Lift-off' conditions (e.g. Humphrey 1987) for thread drifting bivalves. Curves for thread lengths $(L)$ define the individual size (defined as a spherical diameter $D$ ) that can potentially be lifted by hydrodynamic drag exerted by a given vertical velocity on the spherical body and attached long thread (e.g. Lane et al. 1985). Curves for thread lengths use the hydrodynamic drag estimates of Lane et al. (1985). Tensile strength constraint is defined by the dotted line for thread diameter (d) $0.5 \mu \mathrm{m}$. Reynolds number is contoured
$1.8 \mathrm{~mm}$ diameter). For the common range of larval diameters and vertical velocities in the lift-off window, Reynold's number ranges from 0.01 to 10 . Increasing the thread length by an order of magnitude increases the liftable diameter of the thread-drifting bivalve by a factor of 2, while increasing the vertical velocity from $1 \mathrm{~mm} \mathrm{~s}^{-1}$ to $1 \mathrm{~cm} \mathrm{~s}^{-1}$ triples the liftable diameter. For large individuals ( $>1.8 \mathrm{~mm}$ ) and long thread lengths $(30 \mathrm{~cm})$, the inherent forces begin to approach the tensile breaking limit for threads $0.5 \mu \mathrm{m}$ in diameter at vertical current speeds on the order of $1 \mathrm{~cm} \mathrm{~s}^{-1}$. This modeling exercise suggests that vertical velocities generated during downwelling/relaxation events are large enough to suspend thread-drifting bivalves. These results are consistent with our observations that thread drifters were most abundant during downwelling/relaxation events.

Are these thread-drifting juveniles lost from the population? Are they equivalent to larval wastage? Given that thread drifters were found deep in the water, they might be transported to the shore by internal tidal bores (Pineda 1991, Leichter et al. 1998), but this has not been investigated. Both Mytilus trossulus and M. californianus will, however, settle in the subtidal zone. This is apparent in our data; none of the threaddrifting individuals, even individuals 500 to $800 \mu \mathrm{m}$ in length, displayed the characteristic darkening of their shell that occurs after several days residence in the intertidal zone (Trevelyan \& Chang 1987). Large subtidal populations of $M$. trossulus have been described from a variety of habitats around the Kamchatka Peninsula, including on cobble bottoms (Selin \& Lysenko 2006). Large subtidal populations of $M$. californianus have been observed from Baja California to Washington, i.e. over much of the species range (Chan 1973, Paine 1976, Love et al. 1999). These populations tend to form on steep rocky bottoms (pinnacles and cliffs); the populations are often dominated by very large individuals (e.g. >300 mm) (Chan 1973, Paine 1976), and individuals in subtidal habitats tend to grow significantly faster than those in the intertidal zone (Selin \& Lysenko 2006). The much larger size and more rapid growth of individuals in subtidal populations relative to individuals in the intertidal zone, suggests that individuals that recruit into these subtidal populations may have remarkable reproductive output; recruitment into subtidal populations may be a selective advantage. Thread- 
drifting mytilids in offshore waters are clearly not a population sink; they may be transported into the intertidal zone or, given that thread drifting can occur over an extended period (individuals $>2 \mathrm{~mm}$ in length have been observed to thread drift), they may eventually encounter a suitable subtidal habitat.

The concentration of juveniles in the water column was generally quite low, often below 1 ind. $\mathrm{m}^{-3}$. At such low concentrations, could thread-drifting juveniles contribute significantly to recruitment in subtidal populations? The way to think about this problem is not to look simply at the concentration of juveniles, but rather at their flux. Assume a horizontal flow of $10 \mathrm{~cm}$ $\mathrm{s}^{-1}$ and that secondary settlement occurs when an individual is within $1 \mathrm{~cm}$ of the bottom. This latter criteria is probably conservative, as entanglement of the thread with a stationary structure of any sort will cause the juvenile to 'land' (see for example De Blok \& Tan-Maas 1977). Given these hypothetical parameters, approximately $87 \mathrm{~m}^{3}$ of water might bathe (i.e. would pass within $1 \mathrm{~cm}$ of the bottom) each square meter of bottom each day. At a concentration of only 0.1 ind. $\mathrm{m}^{-3}$, secondary settlement of juvenile thread drifters could be around 8.7 ind. $\mathrm{d}^{-1}$ or $>250$ ind. $\mathrm{mo}^{-1}$. Even at very low concentrations, the flux of recruits that pass a potential habitat may lead to enough settlement to establish dense populations.

Owing to the capacity to thread drift, the total pelagic duration of mytilids is potentially much longer than the generally recognized pelagic larval duration (Lane et al. 1985); the total pelagic duration would be the sum of the time spent as a larva (35 to $49 \mathrm{~d}$ in Mytilus trossulus and $9 \mathrm{~d}$ in M. californianus) (Strathmann 1987) plus the time spent as a thread drifter. Assuming that the growth rate of juvenile $M$. edulis is similar to that of $M$. trossulus and $M$. californianus then their growth rates are around $24 \mu \mathrm{m} \mathrm{d}^{-1}$ (Lane et al. 1985). Thread drifting has been observed in individuals up to $2000 \mu \mathrm{m}$ in length (Sigurdsson et al. 1976, Lane et al. 1985); the added pelagic duration due to thread drifting may be as much as $70 \mathrm{~d}$ giving a maximum pelagic duration of 119 and $79 \mathrm{~d}$ for $M$. trossulus and $M$. californianus, respectively. This is, obviously, an upper estimate of pelagic duration as juveniles will spend some unknown portion of this period either on the bottom or thread drifting. This speculative calculation does, however, suggest that a substantial amount of additional alongshore dispersal might occur because of dispersal during thread drifting. Connectivity between mytilid populations is due to larval plus threaddrifting dispersal and there are subtidal populations that may act as stepping stone habitats between isolated intertidal and subtidal populations. Hydrodynamic models of connectivity in mytilids, as well as other bivalves, should take into account the biophysi- cal dynamics during the larval period and during the early juvenile period when thread drifting might occur.

Acknowledgements. This research was funded by a National Science Foundation Small Grant for Exploratory Research (OCE 0715425). Sampling assistance was provided by E. Cooper and L. Draper, the captain of the research vessel operated by the Oregon Institute of Marine Biology. B. Tate ably handled the tedious task of measuring the size of hundreds of tiny mytilids.

\section{LITERATURE CITED}

Bayne BL (1964) Primary and secondary settlement in Mytilus edulis L. (Mollusca). J Anim Ecol 33:513-523

Beukema JJ, de Vlas J (1989) Tidal-current transport of thread-drifting postlarval juveniles of the bivalve Macoma balthica from the Wadden Sea to the North Sea. Mar Ecol Prog Ser 52:193-200

Carlton JT (2007) The Light and Smith manual: intertidal invertebrates from Central California to Oregon. University of California Press, Berkeley, CA

Chan GL (1973) Subtidal mussel beds in Baja California with a new record size for Mytilus californianus. Veliger 16: $239-240$

> De Blok JW, Tan-Maas M (1977) Function of byssus threads in young postlarval Mytilus. Nature 267:558

Greenstone MH (1990) Meteorological determinants of spider ballooning: the roles of thermals vs. the vertical windspeed gradient in becoming airborne. Oecologia 84: 164-168

Humphrey AC (1987) Fluid mechanic constraints on spider ballooning. Oecologia 73:469-477

> Huyer A (1983) Coastal upwelling in the California current system. Prog Oceanogr 12:259-284

Lane DJW, Beumont AR, Hunter JR (1985) Byssus drifting and the drifting threads of the young post-larval mussel Mytilus edulis. Mar Biol 84:301-308

> Leichter JJ, Shellenbarger G, Genovese SJ, Wing SR (1998) Breaking internal waves on a Florida (USA) coral reef: a plankton pump at work? Mar Ecol Prog Ser 166:83-97

Lentz SJ, Trowbridge JH (1991) The bottom boundary layer over the northern California shelf. J Phys Oceanogr 21: $1186-1201$

Love MS, Caselle J, Snook L (1999) Fish assemblages on mussel mounds surrounding seven oil platforms in the Santa Barbara Channel and Santa Maria Basin. Bull Mar Sci 65:497-513

Martel AL (1993) Dispersal and recruitment of zebra mussel (Dreissena polymorpha) in a nearshore area in westcentral Lake Erie: the significance of postmetamorphic drifting. Can J Fish Aquat Sci 50:3-12

Martel A, Chia FS (1991) Drifting and dispersal of small bivalves and gastropods with direct development. J Exp Mar Biol Ecol 150:131-147

Martel AL, Robles C, Beckenbach K, Smith MJ (1999) Distinguishing early juveniles of eastern Pacific mussels (Mytilus spp.) using morphology and genomic DNA. Invertebr Biol 118:149-164

Martel AL, Auffrey LM, Robles CD, Honda BM (2000) Identification of settling and early postlarval stages of mussels (Mytilus spp.) from the Pacific coast of North America, using prodissoconch morphology and genomic DNA. Mar Biol 137:811-818

Moum JN, Perlin A, Klymak JM, Levin MD, Boyd T, Kosro PM (2004) Convectively driven mixing in the bottom boundary layer. J Phys Oceanogr 34:2189-2220 
Nelson TC (1928) Pelagic dissoconchs of the common mussel Mytilus edulis, with observations on the behavior of the larvae of allied genera. Biol Bull (Woods Hole) 55:180-192

Omori M, Ikeda T (1984) Methods in marine zooplankton ecology. John Wiley \& Sons, New York, NY

Paine RT (1976) Biological observations on a subtidal Mytilus californianus bed. Veliger 19:125-130

Peterson WT, Miller CB, Hutchinson A (1979) Zonation and maintenance of copepod populations in the Oregon upwelling zone. Deep Sea Res A Oceanogr Res Pap 26: 467-494

Pineda J (1991) Predictable upwelling and the shoreward transport of planktonic larvae by internal tidal bores. Science 253:548-551

Reynolds AM, Bohan DA, Bell JR (2007) Ballooning dispersal in arthropod taxa: conditions at take-off. Biol Lett 3: $237-240$

Selin NI, Lysenko VN (2006) Size and age composition of populations and growth of Mytilus trossulus (Bivalvia: Mytilidae) in the subtidal area of western Kamchatka. Russ J

Editorial responsibility: Richard Osman,

Edgewater, Maryland, USA
Mar Biol 32:360-368

Shanks AL, Shearman RK (2009) Paradigm lost? Cross-shelf distributions of intertidal invertebrate larvae were unaffected by upwelling or downwelling. Mar Ecol Prog Ser 385:189-204

Sigurdsson JB, Titman CW, Davies PA (1976) The dispersal of young post-larval bivalve molluscs by byssus threads. Nature 262:386-387

Strathmann MF (1987) Reproduction and development of marine invertebrates of the northern Pacific coast. University of Washington Press, Seattle, WA

Trevelyan GA, Chang ES (1987) Light-induced shell pigmentation in post-larval Mytilus edulis and its use as a biological tag. Mar Ecol Prog Ser 39:137-144

Trowbridge JH, Lentz SJ (1991) Asymmetric behavior of an oceanic boundary layer above a sloping bottom. J Phys Oceanogr 21:1171-1185

Zardus JD, Martel AL (2002) Phylum Mollusca: Bivalvia. In: Young CM (ed) Atlas of marine invertebrate larvae. Academic Press, San Diego, CA

Submitted: August 11, 2010; Accepted: January 24, 2011

Proofs received from author(s): April 1, 2011 